Louisiana State University

LSU Digital Commons

Faculty Publications

Department of Biological Sciences

3-1-2017

\title{
Two new Pentaphylacaceae species from southern Central
}

America

Daniel Santamaría-Aguilar

Missouri Botanical Garden

Laura P. Lagomarsino

Missouri Botanical Garden

Follow this and additional works at: https://digitalcommons.Isu.edu/biosci_pubs

\section{Recommended Citation}

Santamaría-Aguilar, D., \& Lagomarsino, L. (2017). Two new Pentaphylacaceae species from southern Central America. Brittonia, 69 (1), 100-108. https://doi.org/10.1007/s12228-016-9453-1

This Article is brought to you for free and open access by the Department of Biological Sciences at LSU Digital Commons. It has been accepted for inclusion in Faculty Publications by an authorized administrator of LSU Digital Commons. For more information, please contact ir@lsu.edu. 


\title{
Two new Pentaphylacaceae species from southern Central America
}

\author{
Daniel Santamaría-Aguilar ${ }^{1}$ and Laura P. Lagomarsino ${ }^{1,2}$ \\ ${ }^{1}$ Missouri Botanical Garden, P.O. Box 299, St. Louis, Missouri 63166-0299, USA; e-mail: \\ daniel.santamaria366@gmail.com \\ ${ }^{2}$ Biology Department, University of Missouri-St. Louis, One University Blvd., Research Building, St. \\ Louis, MO 63121, USA
}

\begin{abstract}
We describe two new species of Pentaphylacaceae: Freziera monteverdensis from Costa Rica and Ternstroemia liesneriana from Panama. Line drawings, color images of living plants for one of the species, and discussions comparing the new species to their presumed closest relatives are provided.

Keywords: Costa Rica, Freziera, Monteverde, Panama, Ternstroemia, Theaceae.

Resumen. Describimos dos nuevas especies de Pentaphylacaceae: Freziera monteverdensis de Costa Rica y Ternstroemia liesneriana de Panamá. Ilustraciones, fotografías en color de la planta viva para una de las especies, así como discusiones comparando las nuevas especies con los parientes posiblemente más cercanos.
\end{abstract}

Pentaphylacaceae (Ericales) is a family of 12 genera and approximately 345 species, most of which were previously placed in Theaceae (Stevens, 2001). Most members of Pentaphylacaceae are trees and shrubs with distichously arranged serrate leaves that develop in a characteristic rolled bud, frequently covered with soft pubescence. Flowers tend to be small with imbricate, usually white petals, numerous stamens with short filaments and relatively long, basifixed anthers. The family comprises three tribes: Pentaphylaceae (one genus with one species), Freziereae (nine genera and ca. 240 species), and Ternstroemieae (two genera and ca. 103 species) (Stevens, 2001; Weitzman et al. 2004). While the family as a whole is pantropical (with relatively low diversity in Africa; Stevens 2001), the two large tribes include a substantial number of Neotropical taxa, particularly in the genera that give these tribes their names: Freziera Willd. (ca. 65 species) and Ternstroemia Mutis ex L. f. (ca. 100 species). Both genera have high species diversity in cloud forests of montane Latin America. Here we add two additional species to Neotropical Pentaphylacaceae, one each of Freziera and Ternstroemia. Both new species are from southern Central America, Costa Rica and Panama, respectively.
Freziera is distributed from Mexico to Brazil and in the Antilles, with the highest species diversity in the Andean mountains of western South America (Weitzman, 1987; Weitzman et al., 2004; Santamaría-Aguilar \& Lagomarsino, 2015; Zorzanelli et al., 2015). Freziera can be distinguished by the combination of distichous leaves with serrate margins, unisexual flowers with an urceolate corolla, uniseriate stamens, the style shorter than the ovary, and a 3-5-lobed stigma (Every, 2009; Weitzman et al., 2004). In a recent treatment of the genus for Costa Rica, nine species of Freziera were recognized (Jiménez \& Santamaría, 2015). The authors of that study adopted a broad, morphologically heterogeneous circumscription of $F$. friedrichsthaliana (Szyszy1.) Kobuski. However, after careful study of additional fertile specimens and focused fieldwork, we have concluded that this broad circumscription encompasses two distinct species, one of which is new to science. With the addition here of this new species to the genus, plus two others that are known from Central America but do not occur in Costa Rica, there are now 10 known species of Freziera in Central America.

Unlike Freziera, Ternstroemia is not limited to the Neotropics. The genus is distributed 
throughout much of tropical and subtropical Asia and America, with a few species also known from tropical Africa (Stevens, 2001; Weitzman et al., 2004). However, the majority of Ternstroemia species are Neotropical (Boom, 1989; Weitzman et al., 2004). Ternstroemia is characterized by pseudoverticillate leaves, laminae with entire to crenulate margins, solitary flowers borne below the leaves, numerous stamens, superior ovaries, indehiscent or irregularly or circumscissilely dehiscent fruits, and seeds with a sarcotesta (Kobuski 1942a, 1942b; Weitzman et al., 2004; Berry \& Weitzman, 2005; Every, 2009). Sixteen species are currently known from Central America (Kobuski, 1942b; Standley \& Williams, 1950; Bartholomew, 1988; Gómez-Laurito et al., 1990; Santamaría-Aguilar et al., 2015). Here, we describe an additional species from the southeastern Cordillera de Talamanca in Panama.

\section{Materials and methods}

The descriptions of the new species are based on material deposited at A, CR, GH, MO and NY; collections from the following herbaria and resources were also consulted: BM, CAY, F, LPB, LSCR, MOL, PMA, SCZ, USM, and the Global Plants on JSTOR website (http://plants.jstor.org). Flowers were rehydrated in ammonia hydroxide for one day and then placed in water until they were sufficiently soft and pliable to be examined under a dissecting microscope. Rehydrated material was then returned to the herbarium specimen. Material was examined under a Leica StereoZoom 5 binocular microscope at 40X. The descriptions and illustrations that follow are based on herbarium material.

\section{New species}

Freziera monteverdensis D. Santam., Lagom. \& Q. Jiménez, sp. nov. Type: Costa Rica, Puntarenas, Zona Protectora ArenalMonteverde, Monteverde, Cerro Amigos, donde se ubican las antenas de televisión, $10^{\circ} 19^{\prime} 00^{\prime \prime} \mathrm{N}, 84^{\circ} 48^{\prime} 00^{\prime \prime} \mathrm{W}, 1600 \mathrm{~m}, 20$ Jul 2010 [fl bud, fr], D. Santamaría \& L. P. Lagomarsino 8204 (holotype: CR; isotypes: BM, CEPEC, GH, MO, NY, PMA). (Figs. 1, 2)

This species is similar to $F$. friedrichsthaliana but differs in its larger leaves and flowers, pistillate flowers with 29-42 staminodes (vs. 22-25), and large fruits (9$11.1 \mathrm{~mm}$ long vs. $6.3-6.5 \mathrm{~mm}$ ) with more numerous seeds [(112-) 275-630 vs. 100-135].

Tree or shrub (4-) 5-12 m tall. Branches cylindrical, fistulose, the outer bark reddish-brown; leafbearing branches angulate or flattened, generally sulcate in the middle, glabrous, densely or sparsely lenticellate, the lenticels whitish, elliptical to rounded. Terminal bud conduplicate-involute, $4.5-9.5 \mathrm{~cm}$ long, densely or sparsely sericeous, the indument mainly on the midrib and lateral veins, trichomes yellowish-white, ca. $0.5-1 \mathrm{~mm}$ long. Leaves with petiole (2-)2.4-3.5 cm long, decurrent on the branch, adaxially canaliculate, abaxially rounded, glabrous, generally conspicuously winged, the wings erect or involute, their margins entire; colleters 1-4 in petiole base, or absent. Laminae (14.3-)16.5-23.7 × (5.4-)5.8-10.5 cm, broadly ovate to oblong-elliptic; base rounded to cuneate, not revolute, both sides equal or weakly asymmetric; apex acuminate, not bearing a seta; margin serrate, with 60-97 teeth per side, each tooth with a black, conical or weakly curved seta, caducous, the seta not ringed by trichomes; adaxial surface glabrous, without pustules; abaxial surface sparsely sericeous, the indument mainly on the midrib and lateral veins, trichomes pale yellow, $0.5-1 \mathrm{~mm}$ long, with or without papillae, when present, reddishbrown (not very conspicuous and in a series along the midrib); midrib flat or distally weakly elevated, glabrous, rugose, pustulate, on adaxial surface, elevated, densely or sparsely sericeous, rounded, pustulate and striate on abaxial surface; lateral veins 13-30 per side (including some intermediate), flat on the adaxial surface, elevated and prominent on the abaxial surface; tertiary veins reticulate, more conspicuous on the abaxial surface. Inflorescences axillary, of 2-4 fasciculate flowers. Flowers with pedicel 6-12 $\mathrm{mm}$ long, terete, erect or weakly curvate, densely or sparsely sericeous; bracts $2.7-$ $4 \times 2.5-3 \mathrm{~mm}$, inserted at the base of pedicel, persistent or caducous, triangular, carinate or not, external surface sericeous or glabrescent, internal surface glabrous, margin entire or rarely with small setae, apex acute, sometimes with black and curved seta at apex, caducous; bracteoles 2, (3-)4-7.5 × 4 $6.5 \mathrm{~mm}$, persistent, opposite or subopposite, at apex of pedicel, unequal, widely ovate or suborbicular, not carinate, external surface densely or sparsely sericeous, internal surface glabrous, margin entire and ciliate, apex rounded, and without seta; sepals 5 , imbricate; outer sepals (4-)5-7.5 × 5-6 mm, widely 


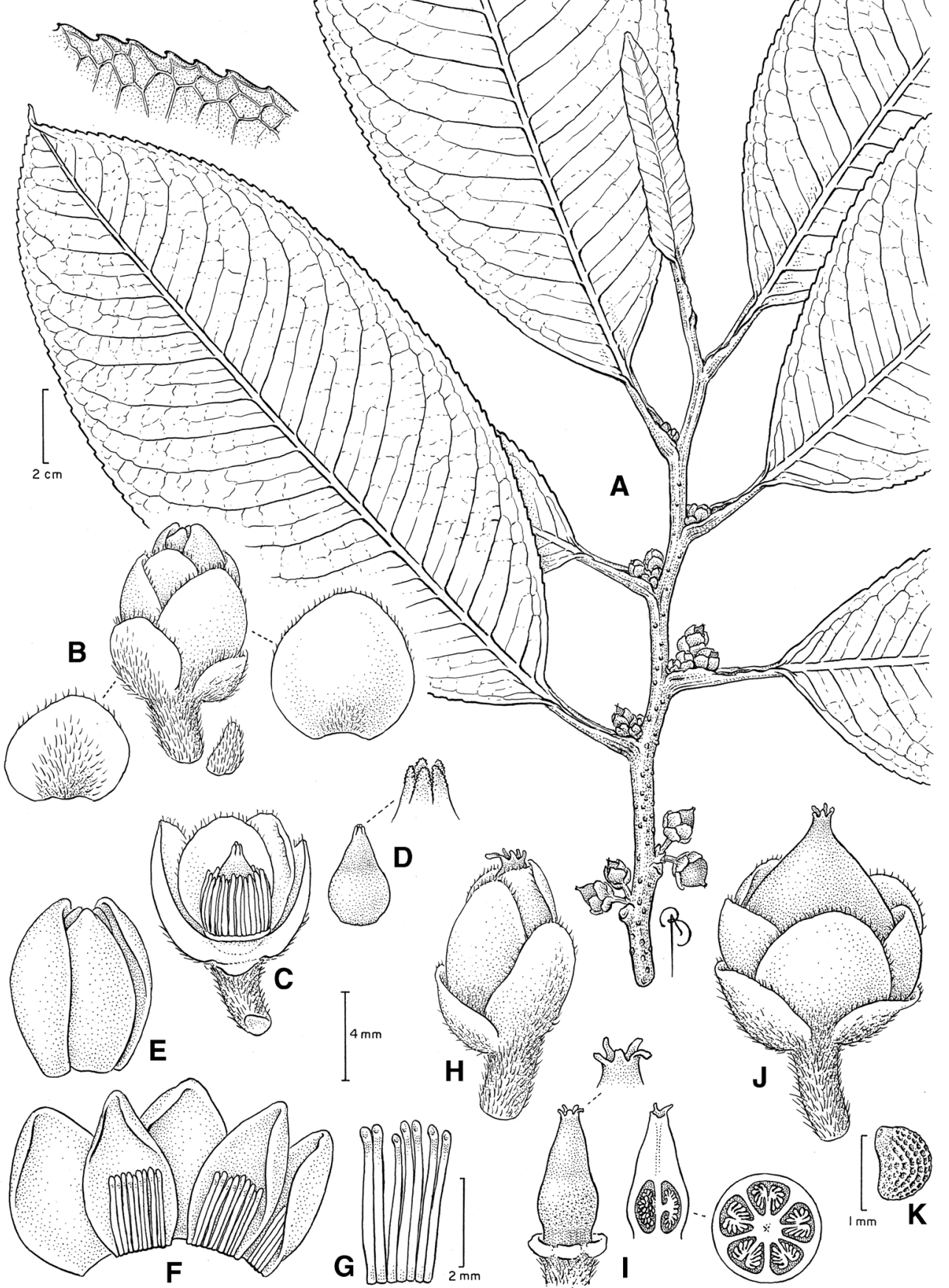

Fig. 1. Freziera monteverdensis. A. Branch with floral buds and fruits; leaf margin detail at upper left. B. Pistillate flower, with detail of bracteole (left), bract (below), and sepal (right). C. Pistillate flower in longitudinal view, with sepals and bracteoles removed to show staminodes and gynoecium. D. Gynoecium and stigma lobes. E. Petals. F. Petals with adnate staminodes. G. Staminodes. H. Flower past anthesis. I. Immature gynoecium (with other floral organs removed), transverse and longitudinal sections of immature gynoecium, and detail of stigma lobes. J. Developing fruit. K. Seed. (A-I from Santamaria \& Lagomarsino 8204; J and K from Santamaría \& Aguilar 9415). 

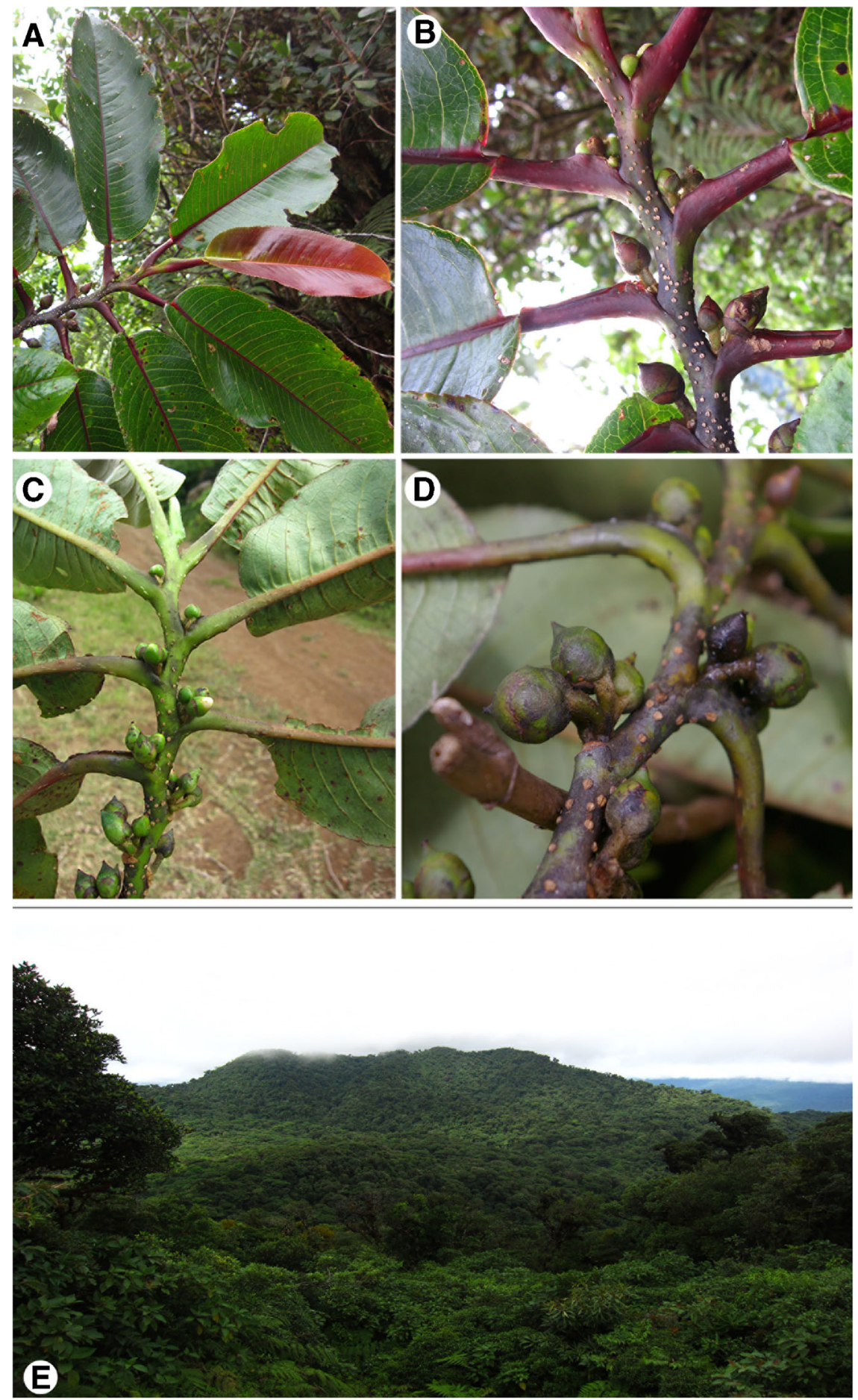

Fig. 2. Freziera monteverdensis. A. Leaves. B. Petioles, showing wings. C. Branch showing abaxial leaf surfaces and flower buds. D. Fruits. E. View of the habitat at the type locality. (A and B from Santamaría \& Aguilar 9413; C from Santamaría \& Aguilar 9414). 
ovate, apex acute or rounded, margin entire and ciliate, chartaceous or membranaceous, external surface glabrescent, sparsely or densely sericeous, the indument mainly on the central or basal part, glabrous to the sides, internal surface glabrous; inner sepals (4-)5-6 $\times(3-) 4-5.3 \mathrm{~mm}$, similar to outer sepals; petals 5, (5-)7-11.5 × 3.3-4.5 mm, white, weakly connate at the base or free, ovate or oblongelliptical, margin membranaceous and entire, apex rounded and reflexed at anthesis. Flower bud 5$7 \mathrm{~mm}$ wide. Staminate flowers unknown. Pistillate flowers with 29-42 staminodes 3-4.2 mm long, free or weakly adnate to the base of the petals, flat, apex rounded or acute; gynoecium 6-7 × 3-4 mm, glabrous, rounded or pyriform, 5-locular; style simple; stigma 5-lobulate, densely papillate. Fruits 9-11.1 $\times$ 7-10 mm, globose, green when immature, purple when ripe, glabrous; fruit wall $0.3-0.5 \mathrm{~mm}$ thick; seeds (112-)275-630 per fruit, reddish-brown or yellowish, shiny, $0.5-1 \mathrm{~mm}$ long, irregularly triangular or rounded, foveolate.

Distribution and habitat:-Freziera monteverdensis is known only from Costa Rica, where it is found on the Caribbean and Pacific slopes of the Cordillera de Guanacaste and the Cordillera de Tilarán in cloud and wet forests, $800-1600 \mathrm{~m}$ in elevation. It has been collected along roads, rivers, and streams and on the borders of volcanic craters. This species is relatively common in the type locality.

Phenology:-Freziera monteverdensis has been collected with flowers buds in January and from October to November, and with pistillate flowers in January and July; staminate flowers have not been collected. Fruits have been collected in February, July, and August, and from October to December.

Etymology:-This species is named for Monteverde, which is both the type locality and the area from which most known specimens have been collected. Monteverde is a district located in the Cordillera de Tilarán in northwestern Costa Rica, floristically dominated by cloud forest. It contains a flora of approximately 2625 species of angiosperms and 358 species of ferns and fern allies, approximately $10 \%$ of which are endemic to Monteverde (Haber 2014a, Haber 2014b). Even though the flora of Monteverde has been well-collected, new species from the region continue to be described (e.g., Barrie, 2004, 2005; Rodríguez, 2006; Morales, 2011; Moura et al., 2012). We now expand the flora to include Freziera monteverdensis, the third species of the genus known from Monteverde. Previously, only $F$. candicans Tul. and $F$. friedrichsthaliana (Szyszył.) Kobuski had been documented.

Additional specimens examined. COSTA RICA. Alajuela: San Carlos, La Fortuna, Finca El Jilguero, borde cratérico, Volcán Chato, sector Sur, $10^{\circ} 26^{\prime} 35^{\prime \prime} \mathrm{N}$, 84²1'25"W, 1140 m, 1 Dec 1992 [fr], G. Herrera 5711 (CR-2 sheets, MO); La Fortuna de San Carlos, 3 km sur Cerro Chato, junto al río Fortuna, $10^{\circ} 25^{\prime} 20^{\prime \prime} \mathrm{N}$, 8441'40"W, 900 m, 7 Nov 1989 [fr], Q. Jiménez \& L. H. Elizondo 732 (CR, MO); Reserva Biológica Monteverde, río Peñas Blancas, alrededores de Quebrada Azufre, $10^{\circ} 21^{\prime} \mathrm{N}, 84^{\circ} 42^{\prime} \mathrm{W}, 700 \mathrm{~m}, 27$ Oct 1987 [fr], W. Haber \& E. Bello 7671 (CR, MO, NY, PMA); San Ramón, Reserva Biológica Alberto Manuel Brenes, sendero de entrada a la estación, $10^{\circ} 13^{\prime} 00^{\prime \prime} \mathrm{N}, 84^{\circ} 37^{\prime} 00^{\prime \prime} \mathrm{W}, 800-850 \mathrm{~m}, 30$ Nov 1997 [fl bud], J. Gómez-Laurito et al. 13046 (CR); Las Lajas, road to Villa Quesada, $1250 \mathrm{~m}, 20 \mathrm{Jan} 1964$ [fl bud], L. H. Holdridge 5206 (CR); Arenal Volcano, SW slope of volcano, 600-700 m, 4 Oct 1991 [fl bud], V. A. Funk et al. 10993 (CR, MO); Cantón de Upala. Bijagua, El Pilón, de la casita de los cazadores, por el Río El Roble, aguas arriba hasta la catarata. Bijagua, $10^{\circ} 41^{\prime} 30^{\prime \prime} \mathrm{N}$, $85^{\circ} 00^{\prime} 20^{\prime \prime W}, 1000$ m, 10 Jul 1988 [fr], G. Herrera 2043 (CR, MO, NY, PMA). Guanacaste: Parque Nacional Rincón de la Vieja, puesto Bullarengo, fila que sube Meseta Aguacatales, entre quebrada Leiva y quebrada Gutiérrez, $10^{\circ} 46^{\prime} \mathrm{N}, 85^{\circ} 49^{\prime} \mathrm{W}, 800-1100 \mathrm{~m}, 4$ Dec 1987 [fr], G. Herrera 1496 (CR-2 sheets, GH, MO, NY, PMA); Tilarán, Lago Coter, hotel Eco-Lodge, sendero Heliconia, $10^{\circ} 35^{\prime} 00^{\prime \prime} \mathrm{N}, 84^{\circ} 36^{\prime} 00^{\prime \prime} \mathrm{W}, 600$ 1000 m, 28 Feb 1997 [fr], G. Rivera \& B. Petruzzi 2876 (CR, MO). Puntarenas: Santa Elena de Monteverde, Cerro Amigos, en la cumbre, orillas del camino, $10^{\circ} 19^{\prime} 13.52^{\prime \prime} \mathrm{N}, 84^{\circ} 47^{\prime} 39.12^{\prime \prime} \mathrm{W}, 1600 \mathrm{~m}, 26$ Jul 2013 [fr], D. Santamaría \& D. Aguilar 9413, 9414 (GH, MO); ibid [ㅇ fl, fr], D. Santamaría \& D. Aguilar 9415 (GH, MO, NY).

Freziera monteverdensis is distinguished by the combination of leaf-bearing branches that are angulate or flattened, glabrous, generally sulcate in the middle, and often densely lenticellate; petioles that are generally conspicuously winged, in addition to being long and thick; large laminae with serrate margins and lateral veins that are prominent on the abaxial surface; and large flowers and fruits, the fruits with many seeds. Some additional distinguishing characters are apparent mainly in the field: leaves with the petiole and adaxial side of the midrib dark red, laminae 
shiny adaxially (a character that remains in some, but not all, herbarium collections), and the youngest flowers hidden under the petiole wings.

This new species resembles Freziera friedrichsthaliana, from Nicaragua and Costa Rica (Fig. 3), with which it was previously confused. Both species have long petioles and sepals that are glabrous or sparsely sericeous on the external surface and leaves of similar shape. However, F. monteverdensis has longer laminae [(14.3-)16.5-23.7 cm vs. $10.5-17 \mathrm{~cm}$ in $F$. friedrichsthaliana], external sepals [(4-)5$7.5 \mathrm{~mm}$ vs. $3.8-4.5 \mathrm{~mm}$ ], and petals [(5-)7$11.5 \mathrm{~mm}$ vs. $4.8-6.5 \mathrm{~mm}]$; pistillate flowers with 29-42 staminodes (vs. 22-25); fruits 9-11.1 mm long (vs. 6.3-6.5 mm); and (112-)275-630 seeds per fruit (vs. 100-135). It is possible to confuse $F$. monteverdensis with some collections of F. calophylla Triana \& Planch. from mainland Costa Rica, but that species differs by its shorter petioles and laminae obtuse or subcordate at the base. Freziera caloneura
Kobuski and $F$. verrucosa (Hieron.) Kobuski from South America also have long petioles and laminae, the latter with numerous lateral veins (which are generally more conspicuous and numerous than in $F$. monteverdensis), but can be differentiated from $F$. monteverdensis by the densely sericeous abaxial surface of their leaves (vs. sparsely sericeous, with the indument mainly on the midrib and lateral veins). Freziera caloneura can further be distinguished by its long bracts (7-12 mm vs. $2.7-4 \mathrm{~mm}$ in $F$. monteverdensis) and subcordate or truncate leaf bases (vs. rounded to cuneate). Freziera verrucosa, on the other hand, differs from $F$. monteverdensis in its short bracteoles (3-4.2 mm vs. [3-]4$7.5 \mathrm{~mm}$ ), smaller, depressed-globose fruits (7-8.7 $\mathrm{mm}$ long vs. globose and 9$11.1 \mathrm{~mm}$ long), and terminal bud that is densely sericeous throughout (vs. densely or sparsely sericeous on the midrib and lateral veins only).

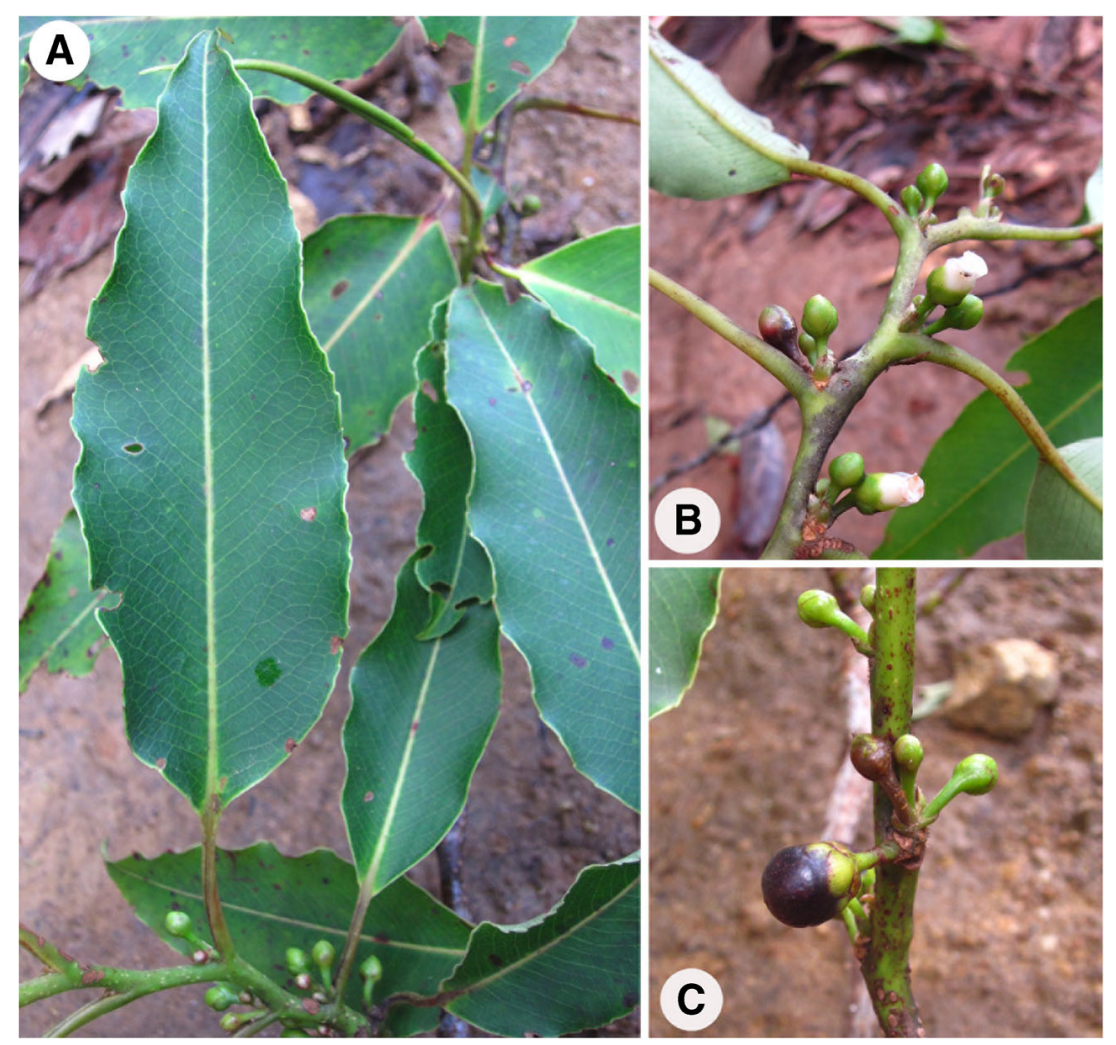

Fig. 3. Freziera friedrichsthaliana. A. Adaxial leaf surfaces. B. Leaf bases, flower buds, and flowers. C. Ripe fruit. (A-C from Santamaría \& Aguilar 9409). 
Ternstroemia liesneriana D. Santam. \& Lagom., sp. nov. Type: Panama, Chiriquí, N of San Félix at Chiriquí-Bocas del Toro border, on Cerro Colorado copper mine road along continental divide, [08 $32^{\prime} 26^{\prime \prime} \mathrm{N}, 081^{\circ} 49^{\prime} 24^{\prime \prime} \mathrm{W}$, 5000-5500 f. [1525-1680 m], 3 May 1975 [fl bud], S. Mori \& J. Kallunki 5791 (holotype: MO; isotypes: CR, NY, digital image). (Fig. 4).

This species is similar to Ternstroemia retusifolia, from which it differs in its leaves lacking black dots and two pairs of bracteoles (vs. one pair).

Tree 3-7 m tall. External bark reddish-gray, longitudinally striate, glabrous. Twigs fasciculate or opposite, cylindrical or weakly angulate. Leaves spirally arranged and clustered toward the branch tips; petiole $0.1-0.4 \mathrm{~mm}$ long, adaxially flattened, rounded abaxially, sometimes with black setae on the margin, glabrous; laminae 1.5-4(-4.8) $\times 0.5$ $1(-1.7) \mathrm{cm}$, oblanceolate, glabrous and generally densely pustulate on both surfaces, black dots absent; lateral nerves generally indistinct, sometimes slightly visible on some leaves (Folsom 6090); midrib canaliculate adaxially, inconspicuously elevated and rounded or flat abaxially; base cuneate and decurrent on the petiole; apex generally weakly retuse or rounded, sometimes acute, with black setae at the apex, these caducous; margin weakly revolute, crenulate, with 6-15 teeth per side, each tooth with a black or reddish-brown, caducous seta. Flowers axillary, solitary, at the apex of the twigs; pedicel 7-10 mm long in unopened flowers, 10 $14 \mathrm{~mm}$ long after anthesis and in fruit, erect or weakly curved (in fruit), terete, weakly compressed, striate, glabrous; bracteoles 2, (1-)1.5-3(-3.5 ) × 2$3(-3.5) \mathrm{mm}$, just below the calyx, opposite or subopposite, unequal, semicircular, glabrous on both surfaces, margin minutely glandular, the glands possibly caducous, apex rounded and generally with black tips. Sepals 5, imbricate, glabrous on both surfaces, rugose on external surface, smooth on internal surface; external sepals ca. 4-5 × 3.5$4.5 \mathrm{~mm}$ in floral bud, 5.5-7 × 5-6 $\mathrm{mm}$ in flower after anthesis and in fruit, obovate, margin entire, sometimes glandular at the base, apex rounded; internal sepals 3-4 × 1.5-2 mm in floral bud, 6$7(-8) \times 5-6 \mathrm{~mm}$ after anthesis and in fruit, obovate to oblong, margin entire, apex rounded or acute. Petals 5, ca. 2-3 × 1-1.6 mm in floral bud, ovate, pink (according to Folsom 6090), margin entire and membranaceous, apex acuminate, fused into tube ca. $1.6 \mathrm{~mm}$ long. Stamens ca. 45-55, weakly united at base; filaments ca. $1.5 \mathrm{~mm}$ long, flat; anthers ca. $1.7 \mathrm{~mm}$ long, connective extending ca. $1.2 \mathrm{~mm}$. Ovary ca. $0.9 \times 1.1 \mathrm{~mm}$ in bud, obovate to subglobose or conical, glabrous, 2-locular, with 4 5 ovules per locule, one locule sometimes sterile; style simple, ca. $1.5 \mathrm{~mm}$ long, straight; stigma punctiform. Fruits $15 \times 10 \mathrm{~mm}$, greenish red, ovoid, glabrous; pericarp ca. $1 \mathrm{~mm}$ thick; style persistent, ca. $3 \mathrm{~mm}$ long; seeds not seen.

Distribution and habitat:-Ternstroemia liesneriana is endemic to Panama and known from only four collections, all from cloud forests at $1300-1700 \mathrm{~m}$ around Cerro Colorado on the border of the provinces of Chiriquí and Bocas del Toro.

Phenology:-Ternstroemia liesneriana was collected with floral buds in May, August, and October, and in fruit in January.

Etymology:- It is an honor to dedicate this new species to Ronald L. Liesner (1944-), curator at the Missouri Botanical Garden, for his labor as a botanical generalist and for his numerous collection efforts in Neotropical countries. He has provided much inspiration and personal support to both authors, especially the first author. He was also the first researcher to annotate a specimen of $T$. liesneriana as a potentially new species.

Additional specimens examined. PANAMA. Bocas del Toro: Chiriquí-Bocas del Toro border, vicinity of Cerro Colorado, along mining road on divide, $8^{\circ} 35^{\prime} \mathrm{N}, 81^{\circ} 50^{\prime} \mathrm{W}, 1300-1400 \mathrm{~m}, 27$ Jan 1989 [fr], G. McPherson 13641 (MO). Chiriquí: Cerro Colorado, $8 \mathrm{~km}$ from main road to Escopeta, along ridge road to top of mountain, border Chiriquí and Bocas del Toro, 14 Aug 1977 [fl bud], J. P. Folsom et al. 4798 (MO); Cerro Colorado, border of Chiriquí and Bocas del Toro provinces, along intersection of Bocas Road with main ridge road, $15.4 \mathrm{~km}$ from Chami [Chame] along ridge road, 1400-1700 m, 24 Oct 1977 [fl past anthesis], J. P. Folsom 6090 (MO).

Ternstroemia liesneriana is similar to T. lineata DC. subsp. chalicophila (Loes.) B. M. Barthol., and T. retusifolia Kobuski. These taxa share several features: various leaf traits, including the size, shape, margin, and apex form, as well as the flower with a simple style and 2-locular ovary. However, T. lineata subsp. chalicophila differs from T. liesneriana by its usually caducous bracteoles (vs. persistent in T. liesneriana) inserted $2.5-5 \mathrm{~mm}$ from the calyx (vs. adjacent to the calyx), or when (more rarely) the bracteoles are persistent and adjacent to the calyx, 


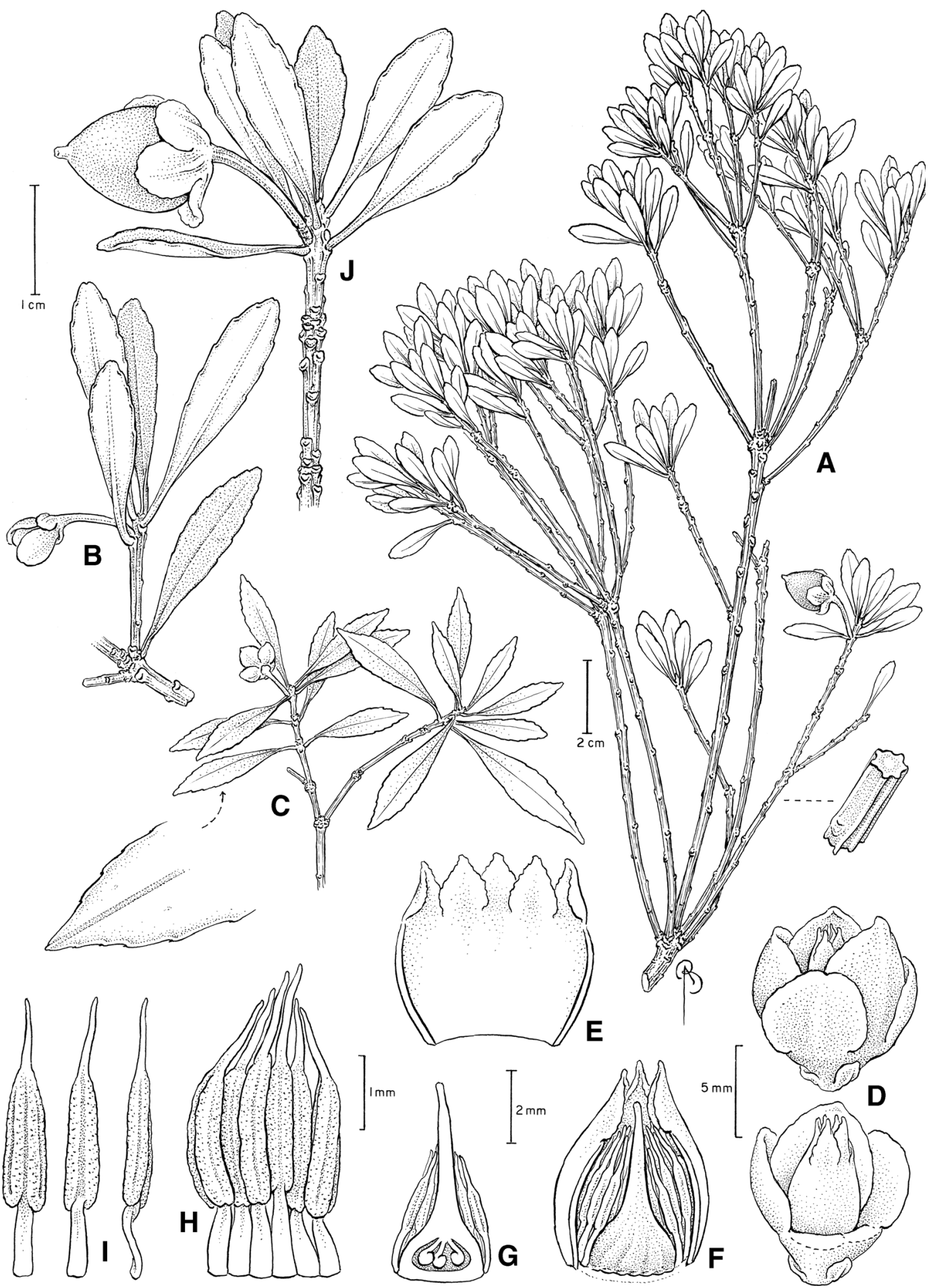

Fig. 4. Ternstroemia liesneriana. A. Branch (showing weakly angulate twigs) with fruit. B. Branch with floral bud. C. Branch with floral bud with a detail of leaf margin. D. Floral bud. E. Corolla. F. Longitudinal view of flower with part of corolla removed to show androecium and gynoecium. G. Longitudinal section through ovary. $\mathbf{H}$ and I. Stamens, showing the extended connectives. J. Branch with fruit. (A and J from McPherson 13641; B from Mori \& Kallunki 5791; C-I from Folsom et al. 4798). 
they are triangular (vs. semicircular); pedicels between $17-40 \mathrm{~mm}$ long and notably curved after anthesis (vs. 10-14 mm and weakly curved or erect); and larger leaves [4.3-7.5 cm long vs. 1.5$4(-4.8) \mathrm{cm}]$. Based on its characterization by Kobuski (1942a), Ternstroemia retusifolia can be distinguished from $T$. liesneriana by its leaves with black dots (vs. absent in T. liesneriana) and two pairs of bracteoles (vs. one pair). Ternstroemia amistadensis Q. Jiménez \& D. Santam. and T. tepezapote Schltdl. \& Cham. are the only other species of their genus known from Panama (Correa et al., 2004; Santamaría-Aguilar et. al., 2015). Both are easily differentiated from $T$. liesneriana by their larger laminae [5-12.6 cm long vs. $1.5-4(-4.8) \mathrm{cm}]$ and larger fruits $(10-23 \times 10-16 \mathrm{~mm}$ vs. $15 \times 10$ $\mathrm{mm}$ ) with a thicker pericarp (1-3.5 mm thick vs. ca. $1 \mathrm{~mm})$. Flowers at anthesis are poorly known for T. liesneriana, and more collections are needed to improve our understanding of the size and shape of the mature floral organs.

\section{Acknowledgments}

We would thank to the directors, curators, and collection managers at A, BM, CAY, CR, F, GH, LPB, LSCR, MO, MOL, NY, PMA, SCZ, and USM for access to their collections and loans; the curators and staff at the Missouri Botanical Garden for their support and hospitality; and Bobbi Angell for the excellent illustrations. Comments by Michael Grayum and Barry Hammel substantially improved the manuscript. LPL was funded by an NSF Postdoctoral Research Fellowship in Biology under Grant No. 1523880.

\section{Literature cited}

Barrie, F. R. 2004. Synopsis of Plinia (Myrtaceae) in Mesoamerica. Novon 14: 380-400.

2005. Thirty five new species of Eugenia (Myrtaceae) from Mesoamerica. Novon 15: 4-49.

Bartholomew, B. M. 1988. New species and a new combination of Mexican Theaceae. Phytologia 64: 457-458.

Berry, P. E. \& A. L. Weitzman. 2005. Ternstroemiaceae. Pp. 300-308. In: J. A. Steyermark, P. E. Berry \& B. K. Holst (eds.). Flora of the Venezuelan Guayana. Vol. 9. Missouri Botanical Garden Press, Saint Louis.

Boom, B. M. 1989. New species of Ternstroemia (Theaceae) from the Guayana Highland. Brittonia 41: 136-142.

Correa A., M., D., C. Galdames. \& M. S. de Stapf. 2004. Catálogo de las plantas vasculares de Panamá. Editora Novo Art, Ciudad de Panamá, Panamá.
Every, J. L. R. 2009 onwards. Neotropical Pentaphylacaceae. In: W. Milliken., B. Klitgård \& A. Baracat, Neotropikey -Interactive key and information resources for flowering plants of the Neotropics. Available from: http://www.kew. org/science/tropamerica/neotropikey/families/ Pentaphylacaceae.htm (Accessed in January 2016).

Gómez-Laurito, J., Q. Jiménez \& N. Zamora. 1990. A new Costa Rican species of Ternstroemia (Theaceae). Brenesia 33: 127-129.

Haber, W. 2014a. Las plantas y la vegetación. Pp. 56-138. In: N. M. Nadkarni \& N. T. Wheelwright (eds.), Monteverde: ecología y conservación de un bosque nuboso tropical. Oxford University Press (versión actualizada y ampliada en español). Available from: http://digitalcommons.bowdoin.edu/scholarsbookshelf/3/. (Accessed December 2015).

— 2014b. Plantas Vasculares de Monteverde. Apéndice 1. Pp. 744-805. In: N. M. Nadkarni \& N. T. Wheelwright (eds.), Monteverde: ecología y conservación de un bosque nuboso tropical. Oxford University Press (versión actualizada y ampliada en español). Available from: http:// digitalcommons.bowdoin.edu/scholars-bookshelf/3/. (Accessed in December 2015).

Jiménez, Q. \& D. Santamaría. 2015. Freziera. Pp. 395-401. In: B. E. Hammel, M. H. Grayum, C. Herrera \& N. Zamora (eds.), Manual de Plantas de Costa Rica. Vol. 8. Monographs in Systematic Botany from the Missouri Botanical Garden 131: 1-657.

Kobuski, C. E. 1942a. Studies in the Theaceae XII. Notes on the South American species of Ternstroemia. Journal of the Arnold Arboretum 23: 298-343.

-1942b. Studies in the Theaceae XIII. Notes on the Mexican and Central American species of Ternstroemia. Journal of the Arnold Arboretum 23: 464-478.

Morales, J. F. 2011. Tres nuevas especies de Meliosma (Sabiaceae) para Costa Rica y Panamá. Journal of the Botanical Research Institute of Texas 5: 545-552.

Moura, T. M., N. Zamora, B. M. Torke, V. F. Mansano \& A. M. G. Azevedo Tozzi. 2012. A new species of Mucuna (Leguminosae-Papilionoidea-Phaseoleae) from Costa Rica and Panama. Phytotaxa 60: 1-8.

Rodríguez, A. 2006. Diez especies nuevas de Guarea (Meliaceae) de Nicaragua, Costa Rica y Panamá. Lankesteriana 6: 101-121.

Santamaría-Aguilar, D., \& L. P. Lagomarsino. 2015. Cuatro nuevas especies y un nuevo registro de Freziera (Pentaphylacaceae) de Ecuador y Perú. Journal of the Botanical Research Institute of Texas 9: 90-102.

- Q. Jiménez \& A. K. Monro. 2015. A new species of Ternstroemia (Pentaphylacaceae) from La Amistad Binational Park and World Heritage Property, Costa Rica and Panama. Phytotaxa 217: 87-91.

Standley, P. C \& L. O. Williams. 1950. Plantas nuevas hondureñas y nicaragüense. Ceiba 1: 74-96.

Stevens, P. F. 2001 onwards. Angiosperm Phylogeny Website. Version 12, July 2012 [and more or less continuously updated since]. Available from: http://www.mobot.org/ MOBOT/research/APweb/ (Accessed in May 2016).

Weitzman, A. L. 1987. Systematics of Freziera Willd. (Theaceae). PhD. Thesis. Harvard University, Cambridge, Massachusetts.

Weitzman, A. L., S. Dressler \& P. F. Stevens. 2004. Ternstroemiaceae. Pp. 450-460. In: K. Kubitzki (ed.), The families and genera of vascular plants. Vol. 6. Flowering 